\title{
O livro dos sonhos
}

\section{The book of dreams}

João Azenha Junior ${ }^{1}$

KLUTE, Johanna; KÜPPER, Klaus - Kinder- und Jugendbücher aus Lateinamerika. Kommentierte Bibliographie der deutschen Übersetzungen. Mit einem Vorwort von Thomas Sträter. [Livros para Crianças e Jovens da América Latina. Bibliografia comentada das traduções alemãs. Com um prefácio de Thomas Sträter]. Köln: Verlag Klaus Küpper, 2015 (Archiv für übersetzte Literatur aus Lateinamerika und der Karibik. Bibliographien, Bd. 3. [Arquivo para literatura traduzida da América Latina e do Caribe. Bibliografias, Tomo 3])

\footnotetext{
${ }^{1}$ Docente da Universidade de São Paulo.
} 


\section{Para situar a obra}

No Brasil, como de resto em grande parte dos países, os Estudos da Tradução desenvolveram-se basicamente a partir de estudos centrados em dois grandes eixos: de um lado, as pesquisas de Literatura Comparada e, de outro, as de Linguística Contrastiva. Um terceiro eixo soma-se aos dois mencionados: o da formação de tradutores e intérpretes, fruto da necessidade de profissionais nesses dois domínios de atividade, intensificada, sobretudo, a partir de meados do século passado, terminadas as duas Grandes Guerras.

Até o início dos anos de 1980, aproximadamente, pesquisas envolvendo obras literárias de diferentes sistemas estruturavam-se preponderantemente sobre bases comparatistas, o texto-fonte (TF) em geral sendo o ponto de partida e de chegada para a análise - e, eventualmente, a crítica - do texto traduzido ou texto-meta (TM). É somente a partir da introdução de uma nova orientação, sob cujo raio de amplitude a historiografia da tradução inclui as abordagens funcionais, bem como as assim chamadas "abordagens sistêmicas", que o interesse de pesquisadores se desloca da base comparatista que pautava a maioria das pesquisas até então para o estudo do texto literário traduzido como um fenômeno concreto, marcado por seu enraizamento num momento histórico e num subsistema literário - o da literatura traduzida -, sem a preocupação em avaliar ou prescrever o modo como tais traduções deveriam ter sido traduzidas, mas tão somente com o intuito de descrevê-las.

Essa mudança de atitude frente ao objeto de estudo - o texto traduzido - pressupõe, então, uma visada que considera o TM mais em sua relação com os demais textos, traduzidos ou não, do sistema literário receptor, do que propriamente em sua relação com o TF. Assim, não que os estudos de base comparatista tenham sido postos de lado, mas os critérios para a descrição das opções de tradução (e, também, para sua avaliação) passam a ter por 
base, fundamentalmente, o impacto de tais traduções em seu sistema receptor.

Do ponto de vista metodológico, a avaliação desse impacto implica um trabalho preliminar que Toury (1995) chama de situar o texto a ser descrito. Isso pressupõe, de partida, um levantamento de informações acerca da obra, nem sempre fáceis de serem coletadas: dados sobre a editora, sobre as reimpressões (ou reedições) da obra, sobre os tradutores, editores, as séries e linhas editoriais em que a obra está inserida, a intervenção de ilustradores, os paratextos mais próximos do miolo do livro tais como notas prévias, posfácios, contracapa, orelha do livro, entre outros, bem como paratextos mais periféricos que sugerem o modo como a editora encaminhou a obra a seu público (por exemplo, os press releases) e o modo como a crítica, especializada ou não, recebeu a obra por meio de resenhas.

Desse modo, o trabalho de base comparatista, pautado pelo rigor de uma metodologia de contornos bem delineados, leva em conta a atuação de normas (TOURY 1995) e de agentes (BANDIA E MILTON 2009), cuja atuação pode ter sido decisiva para a configuração do texto final e pela repercussão da obra entre os leitores do sistema literário que as acolhe.

\section{Sobre os autores e a composição deste livro}

Klaus Küpper e Johanna Klute são aficionados pela literatura da América Latina. Por duas vezes, tive oportunidade de contar com sua valiosa colaboração para dois orientandos que, ao tentarem mapear os primeiros movimentos de recepção, na Alemanha, para as obras de Clarice Lispector e de Carolina Maria de Jesus, tropeçaram na total falta de respostas para todas as suas tentativas de contato com editoras alemãs. Foi ele, Küpper, que não mediu esforços para, generosamente, fornecer aos meus orientandos todas as 
informações que possuía sobre os livros e suas resenhas, permitindo, assim, que os estudantes pudessem compilar seus corpora de trabalho e viabilizar, assim, os objetivos de suas pesquisas.

Conforme lemos no prefácio de Thomas Sträter, Küpper tem dedicado sua vida ao trabalho delicado de acompanhar, registrar e organizar num grande arquivo os movimentos de intercâmbio entre as literaturas da América Latina e a alemã mediados pela tradução. Esse "solitário projeto de um homem só”, como afirma Sträter em seu prefácio (2015: VIII) tem desempenhado, então, o importante papel de suprir as lacunas que, por descuido ou negligência, as editoras têm deixado para trás. Ouso afirmar até mesmo que sem o trabalho incansável desse pesquisador, os trabalhos de grau que se desenvolvem sob essa reorientação dos Estudos da Tradução resumida acima, não poderiam ser levados a cabo.

0 resultado desse trabalho conjunto entre Johanna Klute e Klaus Küpper é um livro que serve de marco para a localização das primeiras informações necessárias ao trabalho de se situarem textos da literatura escrita para crianças e jovens na América Latina, para fins da pesquisa sobre a recepção dessas obras nos países de expressão alemã. Ao livro, ainda sem tradução do alemão, serviu de base o já mencionado "Arquivo para literatura traduzida da América Latina e do Caribe". O volume contém títulos que foram traduzidos do espanhol latino-americano, do português do Brasil, mas também dos países de fala inglesa e francesa da América Latina e do Caribe. Além disso, constam do livro obras presentes em antologias, revistas e outras publicações, bem como manuscritos escritos para a cena, audiolivros e edições para deficientes visuais, além de edições especiais. Ao final encontrase também um CD com as ilustrações de todos os títulos, bem como das quarta-capas e sobrecapas dos livros.

A parte principal traz listados todos os autores em ordem alfabética. A fim de exemplificar a composição desta parte, tomo como exemplo o escritor José Mauro de Vasconcelos (1920-1984), um autor que li e reli na minha 
infância e juventude. É claro que penso em Meu pé de laranja lima, com o qual tive contato como leitor, mas também como espectador da versão televisiva, "refratada", portanto, nos termos de Léfevère (1992), na novela homônima da Rede Globo.

\section{Um exemplo}

A entrada para o escritor José Mauro de Vasconcelos começa com uma série de informações biobibliográficas. E já aí descubro, para minha surpresa, que José Mauro estudou Medicina, Direito, Filosofia, pintura e que exerceu várias profissões: foi pescador, professor, enfermeiro, treinador. Penso, então, nesse homem de várias facetas e de formação ampla, que "reuniu ricas experiências sobre sua pátria; uma pátria que ele sempre percorreu e que the ofereceu os temas para seus numerosos romances" (2015: 156).

A descrição das obras do autor traduzidas para o alemão começa com Die lange Nacht des Häuptlings Kuryala (título original: Kuryala: capitão e carajá), um romance póstumo do autor. Seguem-se, então, uma série de informações: o nome da tradutora alemã, da editora, a $1^{\text {a }}$. edição (1992), o título original, o ISBN, o nome da ilustradora da capa, a tiragem, assim como comentários sobre informações que a edição contém sobre o autor e a história. Vejo também que o mesmo livro recebeu outra edição, dessa vez de bolso, publicada pela mesma editora em 1994. A capa dessa segunda edição é de autoria de outro ilustrador.

Chego, então, a Wenn ich einmal groß bin ou Quando eu for grande, tradução literal do título alemão para a obra talvez mais conhecida de Vasconcelos: Meu pé de Laranja Lima, de 1968. Já em 1970, surge a primeira edição alemã, em tiragem de 6000 exemplares. E a ela se seguem dezenas de outras, das quais cito apenas algumas: outras duas em 1970, depois em 1972, 
1974, 1975, 1977, 1979, outras oito até 1991, mais uma em 1998, depois em 2001 e 2002. As editoras são as mais variadas, de diversas cidades da Alemanha, Suíça e Áustria e englobam, assim, todo o chamado "espaço de fala alemã". Diferentes também são as tiragens e os ilustradores. Duas edições são para deficientes visuais: uma de 1986 e outra de 2002. Em 2009, o livro recebe uma nova edição. A tradutora é a mesma - Marianne Jolowicz -, mas o título é diferente: Mein kleiner Orangenbaum (Minha pequena laranjeira, em tradução literal).

Depois de um breve resumo do enredo da obra, descubro que Meu pé de laranja lima recebeu também uma tradução em formato reduzido, publicada em 1971 e 1977, com o título de Sesé wartet auf das Christkind (Sesé espera pelo Menino Jesus). Leio no livro de Klute e Küpper que se trata de um excerto da obra de Vasconcelos, constituída de dois capítulos com algumas supressões e "21 linhas introdutórias, que não são de autoria de Vasconcelos" (2015: 158).

É só um exemplo. Mas quantas perguntas de pesquisa se poderiam derivar daí? Elenco algumas: a recepção, na Alemanha, da obra de José Mauro de Vasconcelos - em especial de Meu pé de Laranja Lima - é, no mínimo, impressionante. Quais agentes teriam possibilitado a chegada da obra ao sistema literário alemão apenas dois anos depois de ela ter sido publicada no Brasil? O que teria levado a obra a uma recepção de tanto sucesso, corporificada em numerosas edições? Que diferenças se podem perceber entre elas? 0 que a mudança de ilustradores e, por conseguinte, da capa das edições têm a dizer sobre a obra e sua recepção num espaço de cerca de três décadas? Qual o perfil das editoras que a publicaram? Existem ecos da recepção na crítica literária? Porque a mudança de título na edição de 2009? E porque a versão reduzida da obra, publicada paralelamente às demais, com um início "diferente", quer dizer, não de autoria de Vasconcelos? São só alguns exemplos de perguntas de pesquisa. E eu não teria chegado a elas sem o livro de Klute e Küpper. 
De volta ao livro, finaliza esta seção principal uma pequena lista de autores anônimos: escritores desconhecidos da Bolívia, do Brasil, de Cuba e do Peru. E outras perguntas de pesquisa poderiam ser derivadas daí. A parte seguinte é dedicada às antologias, esses importantes fenômenos de refração que nos levam a refletir sobre a as imagens que, num sistema literário, são construídas de outros sistemas literários, em diferentes épocas, pela vitrine das antologias. Esta seção é seguida de outra dedicada a contos de fadas, lendas e outras narrativas. Por fim, os índices: por país (o nome dos autores em ordem alfabética), indicações de bibliografia secundária sobre o tema, isto é, a literatura infantil e juvenil, o índice de tradutores e editores, dos ilustradores e as referências às editoras mencionadas ao longo da obra. No $\mathrm{CD}$, as capas, contracapas e sobrecapas. Procuro aquelas dos livros de José Mauro de Vasconcelos: estão todas lá à espera de serem estudadas sob um ponto de vista estético, semiótico, por exemplo.

Um livro dos sonhos, em todos os sentidos: não só porque focaliza obras nas quais universos infantis e juvenis desenham sonhos que constituem um imaginário, mas também porque convida pesquisadores que trabalham no campo dos Estudos Germanísticos a refletirem sobre o modo como esses sonhos latino-americanos dialogam, através da tradução, com outros sonhos infantis e juvenis de expressão alemã. E, nesse sentido, ele também é o livro dos sonhos desses pesquisadores, pois thes coloca às mãos informações valiosas, sem as quais suas pesquisas correriam o risco de não se concretizarem.

\section{Referências bibliográficas}

EVEn-Zohar, Itamar. "Polysystem Studies: Introduction; The Position of Translated Literature in the Literary Polysystem”. In: Poetics Today, v. 1, n. 1, 1997 
AZENHA JUNIOR, J. - O livro dos sonhos

[1990]. Available in: <http://www.tau.ac.il/ itamarez/works/books/ezpss1990.pdf>.

LEFEVERE, André. Translation, Rewriting and the Manipulation of Literary Fame. London/New York: Routledge, 1992.

MiLton, John; BANDIA, Paul. Agents of Translation. London: John Benjamin, 2009.

TOURY, Gideon. Descriptive Translation Studies and beyond. Amsterdam/ Philadelphia: John Benjamin, 1995.

Data de submissão: 21/11/2016

TradTerm, São Paulo, v. 29, Julho/2017, p. 251-258 -

www.usp.br/tradterm 